\title{
THE RIGHT TO ORAL HEARING IN DISCIPLINARY PROCEEDINGS AGAINST PUBLIC SERVANTS: A MALAYSIAN PERSPECTIVE
}

\section{Zukiferee Ibrahim \& Abdul Majid Tahir Mohamed}

Faculty of Law and International Relations

Universiti Sultan Zainal Abidin, Malaysia

zukifereeibrahim@gmail.com; amtmajid@unisza.edu.my

Received: 14 November 2018 Accepted: 8 April 2019 Published Online: 24 December 2018

\begin{abstract}
The decisions of disciplinary authorities in disciplinary proceedings continue to be judicially reviewed on the grounds of their failure to grant an oral hearing to the affected public servants albeit the wellestablished principle by the Privy Council in Najar Singh's case since 1976. Such failure may implicate the deliverance of justice, and affect the reputation and goodwill of the Malaysian government as the major employer in the nation. The constitutional protection of a reasonable opportunity of being heard to public servants under Article 135(2) in the case of dismissal and reduction of rank should be interpreted in the light of the fundamental right to life as enshrined in the Federal Constitution. The purpose of this article is to examine the approaches of the court in determining the right to an oral hearing in disciplinary proceedings against public servants; and whether the administrative decisions of the disciplinary authorities should be subject to judicial review. This paper forward a submission that the court should adopt a liberal approach in determining the right to an oral hearing in disciplinary proceedings against public servants.
\end{abstract}

Keywords: Natural justice, Right to an oral hearing, Disciplinary proceedings, Public servants, Judicial review.

\section{INTRODUCTION}

The right to be heard is one of the fundamental principles of the rule of natural justice. It gives an opportunity to a party to defend 
his case, and what is more significant, is that it also indicates the manifestation of the deliverance of justice. The term 'natural justice' embodies two maxims, viz., (1) the right to be heard or to a fair hearing, or no man is to be condemned unheard that is referred to in Latin as 'audi alteram partem'; (2) and the rule against bias (or the right to an impartial or unbiased adjudication) that in Latin is known as 'nemo judex in causa sua'. Lord Denning described precisely the principles of natural justice in two words, viz., impartiality and fairness. ${ }^{1}$

The application of the rule of natural justice in disciplinary proceedings against public servants in Malaysia continues to be legal polemics. Despite the principle in Najar Singh's case in 1976, ${ }^{2}$ it remains contentious in court on the failure of the disciplinary authority to grant an oral hearing to the affected public servant. On that premise, this paper will first discuss the concept of natural justice and its application in Malaysia. It will then examine the position of public servants in Malaysia and the protection given to them under Article 135(2) of the Federal Constitution. This will lead to the development of cases law on Article 135(2) and the approaches of the courts in dealing with issues of the right to oral hearing. At the end, the paper proposes solutions to resolve the issue relating to the right to oral hearing in disciplinary proceedings against public servants in Malaysia.

\section{NATURAL JUSTICE}

The concept of natural justice originated two centuries ago, and the term natural justice was often used interchangeably with natural law. ${ }^{3}$ It may be traced back to the case of Cooper $v$ Wandsworth Board of

1 B. Surinder Singh Kanda v. Government of the Federation of Malaya [1962] MLJ 169 at $\mathrm{p} 172$

2 Najar Singh v Government of Malaysia \& Anor [1976] 1 MLJ 203 (PC)

3 MP Jain, 1997, Administrative Law of Malaysia and Singapore, Third Edition, Malayan Law Journal, Kuala Lumpur at p 226 
Works. ${ }^{4}$ Nevertheless, with the case of Ridge v Balwin ${ }^{5}$ in the 1960s, the English common law courts have redeveloped the principles on the procedural requirements under which administrative power must operate. ${ }^{6}$ Prior to Rigde's case, restricted judicial thinking denoted in Nakkuda Ali v Jayaratne 7 a case of Ceylon, where the Privy Council held that no one had a legal right to get a licence, it was a privilege and not a right and therefore, no hearing right could be claimed when a privilege was withdrawn. The restricted approach continued in The Queen v Metropolitan Police Commissioner, ex parte Parker, ${ }^{8}$ where it was ruled by the Court that in exercising the disciplinary authority in matters of discipline, no hearing was necessary.

Meanwhile, the term 'natural justice' in Osborn's Concise Law Dictionary, ${ }^{9}$ is defined as:

The rule and procedure to be followed by any person or body charged with the duty of adjudicating upon disputes between, or the rights of others, e.g., a government department. The main rules are to act fairly, in good faith, without bias, and in judicial temper; to give each party the opportunity of adequately stating his case, and correcting or contradicting any relevant statement prejudicial to his case, and not to hear one side behind

4 (1863) 14 CBNS 180; 143 ER 414. In this case, the Board demolished the plaintiff's house without giving him the right of hearing. The statutory provi sion required that no one could put up a house in London without giving seven days' notice to the local Board. In default of such notice, the Board can demolish the house. Accordingly, on the failure of the plaintiff to follow this requirement, his house was demolished on the power given by the statute to the Board. The Board argued that the principle of hearing applied only judicial proceedings while in ordering the demolition it did not perform such act. However, the court ruled the Board was acting judicially as it had to determine the offense and apportion punishment as well as the remedy. Therefore, the plaintiff was entitled to the right of hearing. The principle was laid down that when an authority is by law provided with the power to affect the property of a person it is bound to give him a hearing before it proceeds to affect his property.

5 [1964] AC 40 House of Lords

6 Peter S Crook, Natural Justice and the Constitution: Recent Cases From the Court of Appeal, Journal of Malaysian and Comparative Law, Vol. 23 Part 1 \&2, June and December 1996, 37-56 at p 37

[1951] AC 66

[1953] 1 WLR 1150

Roger Bird, 1983, Osborn's Concise Law Dictionary, 7th Edition, London Sweet \& Maxwell, at p 227 
the back of the other. A man must not be a judge in his cause so that a judge must declare any interest he has in the subject matter of the dispute before him. A man must notice of what he is accused. Relevant documents which are looked at by the tribunal should be disclosed to the parties interested.

The doctrine of natural justice, therefore, observes the execution of procedural fairness in a decision-making process since procedural fairness is an integral part of Administrative Law. However, the expression of natural justice has been criticised in McInnes $v$ Onslow-Fane ${ }^{10}$ and the term "fairness" or "duty to act fairly" was instead preferred in the dicta of Megarry VC.

Furthermore, the notion of procedural fairness that underlies the rules of natural justice had not been clearly defined in the constitutional terms of the Malaysian context until changes began in early 1995 when the doctrine of administrative fairness was highlighted by the Court of Appeal's decision in Raja Abdul Malek Muzaffar Shah bin Raja Shahruzzaman v Setiausaha Suruhanjaya Pasukan Polis \& Ors. ${ }^{11}$ In this case, the plaintiff submitted the issues of appeal in the traditional term of natural justice. Instead of the rules of natural justice, the Court of Appeal considered the issues raised to be more appropriately described as involving procedural fairness where Gopal Sri Ram JCA preferred the term 'procedural fairness' instead of 'rules of natural justice' since the term of procedural fairness includes but not limited to the rules of natural justice. ${ }^{12}$

In terms of execution in the administrative field, Prof. Jain (1997) $)^{13}$ explained lucidly the circumstances when an aggrieved person with administrative action could claim natural justice. He opined that this issue has no ready-made formula yet where it has to be considered in every situation and based on the decided cases, it can be implied that the courts' approach was to apply the principle of natural justice in the case of a 'quasi-judicial' function, as distinguished from a merely 'administrative' one. Lord Reid delivering the leading judgment of the House of Lords in Ridge $v$ Balwin pointed out that the concept of

\footnotetext{
[1978] 1 WLR 1520

[1995] 1 MLJ 308

Peter S Crook at p 38

MP Jain at $\mathrm{p} 228$
} 
natural justice was vague, that there was no reason for applying it. ${ }^{14}$ As time went by, Ridge $v$ Balwin led to the broader application of the right of hearing in administrative processes which was considered as "a metamorphosis took place in judicial thinking" when the duty to observe the rules of natural justice came to be imposed not only in quasi-judicial functions but included some bodies exercising analytically administrative functions. ${ }^{15}$

\section{APPLICATION OF NATURAL JUSTICE IN MALAYSIA}

In the local context, the Federal Court in Fadzil bin Mohamed Noor $v$ Universiti Teknologi, Malaysia ${ }^{16}$ referred the House of Lords' decision in Ridge $v$ Balwin where Lord Reid said inter alia that in a pure master and servant case, dismissal was governed by the law of contract inter partes, and no right to be heard. What was meant here, in a pure master and servant relationship, is that the principles of administrative law, including those of natural justice have no part to play unlike the case of the appellant where he was an Assistant Lecturer and was later dismissed by the respondent. The High Court dismissed his application for a declaration of unlawful dismissal, but on appeal to the Federal Court, it was successful. Raja Azlan Shah CJ referred to the decision in Ridge v Balwin. The Federal Court highlighted in the appellant's case, that it was not a straightforward matter of master and servant. The appellant's status as Assistant Lecturer employed by the University was a status supported by statute and was entitled to the protection of a hearing before an appropriate disciplinary authority, which did not happen in this case when the University Council dismissed the appellant without any right of hearing. The significance of Fadzil's case lies in the acceptance by the Federal Court that the relation between a university (which is the statutory body) and a member of its academic staff has an element of public employment in it and is not purely a matter of ordinary master and servant relationship. The Federal Court referred to the principle in Mullock $v$ Abeedeen Corporation ${ }^{17}$ when Lord Wilberforce pointed out that in cases where an element of public employment or service, supported by statute, "there may be essential

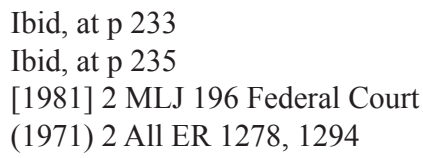


procedural requirements to be observed, and the failure to observe them may result in a dismissal being void". As such, therefore, the university has to follow natural justice before dismissing a member of its academic staff. ${ }^{18}$

\section{THE POSITION OF PUBLIC SERVANTS IN MALAYSIA}

Malaysia had a total of 1.6 million public servants ${ }^{19}$ in four main sectors: administration, education, health and security in 2017. The Malaysian Public Service also includes State Public Services that have historically existed before Merdeka Day in every Federated or Unfederated Malay State. ${ }^{20}$ The data includes employees of local authorities and statutory bodies either at federal or state level. Despite this fact, for the purposes of the Federal Constitution, Article 132(1) limits specific services as members of the public service in Malaysia to certain services only. Those services are (a) the armed forces, (b) the judicial and legal service, (c) the general public service of the Federation, (d) the police force, (e) the joint public services mentioned in Article 133, (g) the public service of each State and (h) the education service.

Shad Saleem $(2010)^{21}$ draws our attention to this issue where he mentions that employees of statutory bodies are not members of the public service. This is in line with the phrase "for the purpose of this Constitution" in Article 132 which tends to limit the members of public service. He supports his argument with the case of Ramalingam s/o Muthusamy $v$ Chong Kim Fong. ${ }^{22}$ In that case, it was held that officers of the Federal Land Development Authority ${ }^{23}$ were not public service officers within the meaning of Order 43 rule

\footnotetext{
18 MP Jain, at $\mathrm{p} 263$

19 Suhaila Shahrul Anuar, Jumlah penjawat awam munasabah, Berita Harian Online, 19 April 2017. https://www.bharian.com.my/node/273436 [2 December 2017]; Annual Report JPA, 2013

20 Nik Ahmad Kamal Nik Mahmood, 2003, Perkhidmatan Awam, In. Ahmad Ibrahim, Faiza Thamby Chik, Ramlah Muhammad, Asiah Daud \& Ismail Hassan (Eds.), Perkembangan Undang-Undang Perlembagaan Persekutuan, pp. 231-273, Dewan Bahasa dan Pustaka, Kuala Lumpur, p. 232.

${ }^{21}$ Shad Saleem Faruqi. 2008. Document of Destiny, The Constitution of the Federation of Malaysia, Chapter Public Service, Star Publication Berhad.

22 [1978] 1 MLJ 83

23 Federal Land Development Authority is a body established by Section 3 of Land Development Act, 1956 [Act 474]
} 
5(2) of the Rules of the Supreme Court, 1957. ${ }^{24}$ Public services under the Interpretation Act 1948 means the public services mentioned in Article 132 (1) of the Federal Constitution, which sets out a list of public services. However, the Federal Land Development Authority is not one of the services mentioned in the Constitution.

On the employees of local authorities, the Federal Court in Mohd Ahmad v. Yang Di-Pertua Majlis Daerah Jempol, Negeri Sembilan and Anor ${ }^{25}$ held that employees of local authorities (under the Local Government Act 1976) were not holders of public offices and were not under any category under Article 132 of the Federal Constitution, except any employee in any local authority seconded from the State Government or the Federal Government. Similarly, in Rosnelli Kundor v Kelantan State Economic Development Corporation ${ }^{26}$, the Court of Appeal held that the appellant, who was the employee of the respondent (a body incorporated) and holding a permanent and pensionable post, was not a public servant within the meaning of Article 132 of the Federal Constitution.

It is contended that the intention of the framer of the Federal Constitution in using the term 'for the purpose of this Constitution' is to limit the constitutional protection under Article 135 only to public services as prescribed in Article 132 (1). However, the scope and recognition of public servants are broader under different legislations like the Penal Code. ${ }^{27}$

The objectives of this paper are to examine the constitutional provisions, statutory provisions, and regulations on the issue of the right to oral hearing in disciplinary proceedings against public servants in Malaysia; and to analyse the approach of the courts in dealing with this issue.

\section{LITERATURE REVIEW}

In general, the literature contains various collections on the rule of natural justice and the right to be heard. Nonetheless, there is

24 Order 43 rule 5(2) of the Rules of the Supreme Court, 1957 inter alia is on the garnishee proceedings regarding property under the custody and control of a federal officer in his official capacity.

25 (1997) 3 CLJ 135

26 (2004) 4 CLJ 492

27 Section 21 Penal Code 
no literature which exclusively explores the right to oral hearing in disciplinary proceedings in Malaysia. For example, Romli et al. $(2012)^{28}$ discussed the rule of natural justice concerning disciplinary proceedings in the Police Department. The writers shared their opinion that the rule of natural justice is the minimum requirement in the decision-making process by a quasi-judicial body, like the Disciplinary Authority. The article also mentioned that in the deliverance of justice, the responsibility of the Disciplinary Authority is not merely to submit to statutes and regulations, but also to ensure that the rule of natural justice is given to the relevant employee. However, there is no de nisi or specific explanation on the issue of the right to oral hearing in disciplinary proceedings although the article agreed that the rule of natural justice was vastly applied in disciplinary proceedings among police officers in Malaysia.

Prof. Jain (1997) a leading authority in Administrative Law in the Commonwealth wrote a book in this area of law on natural justice. ${ }^{29}$ The various developments in this area of law are updated in the book; however its contents are valid until 1997. A specific chapter is dedicated to natural justice to discuss related issues and cases on the right to oral hearing. According to the author, natural justice has no precise definition of its contents. It has to be applied to the proceedings of a wide spectrum of decision- making bodies and inquiries like disciplinary proceedings against government servants. ${ }^{30}$ Since the book was published in 1997, it lacks the views and comments on landmark cases on the right to oral hearing such as Utra Badi, Yusuf bin Sudin, and Tay Chai Huat.

Gan Ching Chuan (2007) ${ }^{31}$ shed some light on this research when he discussed issues of disciplinary procedure and its related applications in the rule of natural justice and the right to oral hearing. The author argued that the right to a fair hearing is the sine qua non of the modern administrative process, which is part of the fundamental

28 Fariza Romli, Nuarrual Hilal Md Dahlan, \& Rusniah Ahmad, 2012, Prinsip Keadilan Asasi Dalam Undang-Undang Berkaitan Prosedur Perbicaraan Tatatertib di Jabatan Polis: Suatu Analisa. UUM Journal of Legal Studies 3: 145-163.

29 MP Jain, Administrative Law of Malaysia and Singapore, Third Edition, 1997, Malayan Law Journal, Kuala Lumpur

$30 \quad$ Ibid at p. 289

31 Gan, Ching Chuan, 2007, Disciplinary Proceedings Against Public Officers in Malaysia, Lexis Nexis, Singapore. 
rights in several modern constitutions. Article 135(2) of the Federal Constitution has constitutionalized the rule of natural justice which is developed from the common law.

\section{CONSTITUTIONAL PROTECTION UNDER ARTICLE 135(2)}

Article 135(2) of the Federal Constitution ${ }^{32}$ adopts the common law concept of natural justice. It gives the right to a reasonable opportunity to be heard to a member of public service in case of dismissal or demotion. Because of that provision, public servants have to be accorded with such an opportunity before an action of dismissal or reduction in rank can be meted out against them. In this regard, Raja Azlan Shah in Ketua Pengarah Kastam vs. Ho Kwan Seng ${ }^{33}$ decided that:

The rule of natural justice that no man may be condemned unheard applies to every case where an individual is adversely affected by an administrative action, no matter whether it is labelled "judicial", "quasi-judicial", or 'administrative' or whether or not the enabling statute makes provisions for a hearing.

All members of public services under the Federal Constitution, unless provided otherwise are subject to the Public Officer (Conduct and Discipline) Regulations 1993. However, Rusniah Ahmad (2013) $)^{34}$ pointed out the limitations of the constitutional guard in Article 135(2) since it applies only to cases with the purpose of dismissal or reduction in rank. In terms of application, natural justice can be limited by legislation. Even the Federal Constitution itself limits the application of natural justice in cases as enunciated in clause (2) of Article 135. The exceptions arise when a criminal charge has been proved against the relevant officer, a situation where the

\footnotetext{
32 Article 132(2) of the Federal Constitution states "no member of such a service as aforesaid shall be dismissed or reduced in rank without being given a reasonable opportunity of being heard": Federal Constitution, 2010, pp. 124.

33 [1977] 2 MLJ 152

34 Rusniah Ahmad, 2013. Applikasi Prinsip dan Kes-Kes Tatatertib, In Sistem Pengurusan Tatatertib di Tempat Kerja, pp. 68-101. Penerbit Universiti Utara Malaysia.
} 
disciplinary authority is satisfied that it is not reasonable to carry out the requirement of the reasonable opportunity of being heard and when it involves an order of detention, restriction, etc. ${ }^{35}$

\section{DEVELOPMENT OF LAW CASES IN MALAYSIA}

Article 135(2) specifically mentions the protection of 'reasonable opportunity of being heard' in any case of dismissal or reduction in rank against public servants. The term 'reasonable opportunity of being heard' was replicated in the Public Officer (Conduct and Discipline) Regulations 1993 as provided in Regulation 34. ${ }^{36}$ Despite this provision, in any proceedings of dismissal or reduction in rank, Regulation $37^{37}$ limits such right to a written representation.

35 Article 135(2): No member of such a service aforesaid shall be dismissed or reduced in rank without being given the opportunity of being heard:

Provided that this Clause shall not apply to the following cases:

(a) where a member of such a service is dismissed or reduced in rank on the grounds of conduct in respect of which a criminal charge has been proved against him; or

(b) where the authority empowered to dismiss or reduce in rank a member of such a service is satisfied that for some reason, to be recorded by that authority in writing, it is not reasonably practicable to carry out the requirements of this Clause; or

(c) where the Yang di-Pertuan Agong, or, in the case of a member of the public service of a State, the Ruler or Yang di-Pertua Negeri of that State, is satisfied that in the interests of the security of the Federation or any part thereof it is not expedient to carry out the requirements of this Clause; or

(d) where there has been made against a member of such a service any order of detention, supervision, restricted residence, banishment or deportation, or where there has been imposed on such a member any form of restriction or supervision by bond or otherwise, under any law relating to the security of the Federation or any part thereof, prevention of crime, preventive detention, restricted residence, banishment, immigration, or protection of women and girls:

36 Regulation 34: Case of dismissal or reduction in rank

(1) Subject to sub regulation (2), no officer shall be dismissed or reduced in rank in any disciplinary proceedings under this Part unless he has first been informed in writing of the grounds on which such action is being proposed and he has been afforded a reasonable opportunity of being heard.

37 Regulation 37: Procedure in disciplinary cases with a view to dismissal or reduction in rank

(1) If it is determined under sub regulation 35(2) that the disciplinary offence complained of against an officer is of a nature that warrants a punishment of dismissal or reduction in rank, the Chairman of the appropriate Disciplinary Authority to which the case is referred shall consider the available information. 
The issue of the right to oral hearing in disciplinary proceedings has repeatedly been brought to court. The well-established precedent on the issue of the right to oral hearing was decided by the Privy Council in Najar Singh's case where it was laid down that "the right to be heard does not in all cases include the duty to afford an oral hearing....". The appellant, in this case, was a sergeant major in the police force. On 31 May 1971, he was served with an order of detention under section 8(1) (a) of the Internal Security Act 1960 for two years commencing from 7 June 1971. He was released unconditionally on 25 January 1972. During his detention, the Inspector General of Police sent him a letter dated 5 July 1971 asking him to show cause why he should not be dismissed from the police force, which he sent a reply forthwith. Later, on 18 August 1971, he was dismissed from the police force. He challenged the order of dismissal but it was dismissed by the High Court and also by the Federal Court. His further appeal was brought to the Privy Council on two grounds. Our concern is on the second ground that the dismissal was contrary to natural justice and regulations 27 of Chapter D Regulations 1969; he was not afforded a reasonable opportunity of being heard orally before he was dismissed. It was held by the Privy Council on this issue that:

(2) Although regulation 27 of the Chapter D Regulations 1969 stipulated that the appellant should be given a reasonable opportunity of being heard before his dismissal, it was not to be interpreted as imposing an obligation to hear the appellant orally. What was important was that the appellant should be given a full opportunity of stating his case before he was dismissed. As the appellant availed himself of the opportunity, his

(2) If it appears to the Chairman of the appropriate Disciplinary Authority that there exists a prima facie case against the officer, the Chairman of the appropriate Disciplinary Authority shall-

(a) direct that a charge containing the facts of the disciplinary offence alleged to have been committed by the officer and the grounds on which it is proposed to dismiss the officer or reduce his rank be sent to the officer; and

(b) require the officer to make, within a period of twenty-one days from the date he is informed by notice in accordance with regulation 52 of the charge, a written representation containing the grounds upon which he relies to exculpate himself. 
plea that there was a denial of natural justice ought to be rejected.

In this case, Lord Viscount Dilhorne ruled that the word heard does not invariably connote an oral hearing. According to the Lordship, Regulation $27^{38}$ has to be read with Regulation $30^{39}$ and that makes no provision for an oral hearing if the officer fails to make representations in writing or the representations he makes in writing do not exculpate him. It is only if a committee of inquiry is appointed that he will be given the opportunity of giving oral evidence. Regulation 27 is not to be interpreted as imposing an obligation to hear an officer orally.

The principle in Najar Singh's seems to be followed in many cases. Privy Council in Zainal bin Hashim v Government of Malaysia ${ }^{40}$ approved and adopted the proposition in Najar Singh's that hearing does not connote oral hearing. It is interesting to note that incidentally, the judgment in Zainal Hashim's case was also delivered by Lord Viscount Dilhorne, the presiding lord in Najar Singh's case.

In Ghazi bin Mohd Sawi v Mohd Haniff bin Omar, Ketua Polis Negara, Malaysia \& Anor ${ }^{41}$ on the issue of the right to be heard orally, Najar Singh and Zainal Hashim were referred, and even the court constrained themselves to follow both cases. In this respect, a passage of the judgement of Jemuri SCJ was reproduced, where he reminded that:

There should not be any more lingering doubt as to what the phrase 'right to be heard' or 'opportunity of being heard' mean at common law or in a statute, and must be accepted that the issue has been settled, as well as can be on the authorities cited above. Therefore, this point is cadit quaestio.

\footnotetext{
38 Regulation 27 (Chapter D Regulations 1969):

In all disciplinary proceedings under this Part no officer shall be dismissed or reduced in rank unless he has been informed in writing of the grounds on which it is proposed to take action against him and has been afforded a reasonable opportunity of being heard.

39 Regulation 30(1) to (7) deals with the procedures to be followed in cases where dismissal or reduction in rank may be involved.

40 [1979] 2 MLJ 276 Privy Council

$41 \quad$ [1994] 2 MLJ 114 Supreme Court
} 
In fact, in Ghazi, the Supreme Court thought that it was unnecessary to review all the authorities on the right of oral hearing, but stated it was sufficient to refer to Najar Singh's case. However, counsel for the appellant argued that in this kind of situation since dismissal was a serious matter affecting livelihood, it was reasonable for the appellant to expect that there should be an oral hearing. The appellate counsel also repeatedly argued that there was a special circumstance in the appellant's case to warrant an oral hearing, but in the court's view, this argument was untenable since there was no evidence to support it. The approach of the court was to be aware that in dealing with General Orders that have legislative effect, they must not add words to them, which were never intended. In supporting this argument, the judgement of Barwick CJ in Twist $v$ Randwick Municipal Council [1976] 136 CLR 106 at p110 was referred:42

.... if the legislation has made provision for that opportunity to [be heard] to be given to the subject before his person or property is so affected, the court will not be warranted in supplementing the legislation, even if the legislative provision is not as complete as the court might think appropriate. Thus, if the legislature has addressed itself to the question whether an opportunity should be afforded the citizen to be relevantly heard and has neither made it clear that no such opportunity should be afforded, the court is bound by the legislation as much as is the citizen, has no warrant to vary the legislative scheme.

This argument was regarded to be the wrong approach by Prof. Jain $(2007)^{43}$ where he argued (p. 279) that:

The concept of 'reasonable opportunity' in article $135(2)$ is the root concept provided by the Constitution.

42 On the right to be heard orally, the court also referred to the judgement of Lord Bridge of Harwich in Lloyd v McMahon [1987] AC 625 where the Lord said inter alia at $\mathrm{p} 702$ :

... it is well-established that when a statute has conferred on anybody the power to make decisions affecting individuals, the court will not only require the procedure prescribed by the statute to be followed but will readily imply so much and no more to be introduced by way of additional procedural safeguards as will ensure the attainment of fairness.... at $\mathrm{p} 496$.

43 MP Jain at $\mathrm{p} 279$. 
The scope of 'reasonable opportunity'cannot, therefore, be curtailed by legislation. It has to be defined by the courts in accordance with the principles of natural justice. Therefore, while the regulations may be applied insofar as they confer procedural safeguards on government employees if they are found to fall short of principles of natural justice in any way, then the court ought to imply natural justice because that is guaranteed by the Constitution.

The case of Raja Abdul Malek Shah Muzafar Shah bin Raja Shahruzzaman $v$ Setiausaha Pasukan Polis \& Ors ${ }^{44}$ was regarded as the emergence of the constitutional development of the doctrine of administrative fairness since the notions of procedural fairness which is significantly connected with the rule of natural justice has not been clearly defined in constitutional terms though firmly rooted in the Malaysian common law. ${ }^{45}$ In this case, the plaintiff was dismissed as a police officer on charges of misconduct. He challenged the Commission's decision on the grounds of violation of the right under Article 135(2) but was unsuccessful in the High Court. Thus he proceeded further to the Court of Appeal. The appeal was grounded on two issues: (i) failure of the Commission to give him an oral hearing; and (ii) he was denied a reasonable opportunity to be heard since he was not given the opportunity to access and comment on all the information that was used against him.

The Court of Appeal did recast his argument on the rule of natural justice but considered the issue to be more appropriately described as involving procedural fairness. The Court of Appeal through Gopal Sri Ram JCA (as he then was) observed that the notion of procedural fairness raised larger issues of constitutional dimension, particularly the impact of Article 8(1) of the Federal Constitution ${ }^{46}$ (at $p$ 315):

At the heart of the plaintiff's initial submission lies the concept of procedural fairness in its broader application. I prefer the term 'procedural fairness' to the traditional nomenclature 'rules of natural justice.' It is

44 [1995] 1 MLJ 308 Court of Appeal.

45 Peter S Crook at $\mathrm{p} 38$.

46 Article 8: Equality

8. (1) All persons are equal before the law and entitled to the equal protection of the law. 
a concept that includes but it is not limited to the rules of natural justice. It is a very interesting area of law. When I commenced writing this judgment, I was sorely tempted to deal with the full breadth of the argument advanced by counsel. It would have involved, amongst other matters, a historical examination of the concept of procedural fairness, a discussion on the effect upon administrative actions of the humanizing provisions of Art 8(1) as explained by the Privy Council in Ong Ah Chuan v PP [1981] AC 648 at pp 670-671; [1981] 1 MLJ 64 at pp 70-71 and, of course, a consideration of the full impact of the landmark decision in Dewan Negeri Kelantan v Nordin bin Salleh \& Anor [1992] I MLJ 697. It is, as I have said, a very interesting area of the law that has offered me much temptation to enter upon a discussion of it.

Despite the principles of the preceding cases, the Court of Appeal in Ann Seng Wan v. Suruhanjaya Polis Diraja Malaysia \& Anor, ${ }^{47}$ in interpreting the relevant provisions on the right to be heard that is O.26 of the General Order $1980^{48}$ inter alia ruled out that since there was no evidence to contradict the appellant's exculpatory statement, it would be justifiable to hold an oral hearing.

Meanwhile, in Yusof Sudin v. Suruhanjaya Perkhidmatan Polis \& Anor ${ }^{49}$ Zulkefli Makinuddin FCJ when allowing the appeal gave inter alia the following judgement;

When there is a request by the public officer for an oral hearing after he had denied all the charges and appeared to have exculpated himself by furnishing credible evidence in his representation letter, by virtue of O.26(5) of the General Orders 1980, the officer should be accorded an oral hearing to satisfy the requirement of Article 135(2) of the Federal Constitution. It would become all the more necessary for the oral hearing or

[2002] 1 CLJ 493

48 Order 26 General Order 1980 states the procedures of the disciplinary proceeding.

49 2012] 1 CLJ 448 at $\mathrm{p}$ 450. In this case, the appellant prayed in his letter for an oral hearing by way of an inquiry to be given to him in the event his explanation was deemed insufficient to exculpate himself from the charges against him. 
enquiry to be held if there was no evidence to contradict the public officer's exculpatory statement. (Ann Seng Wan v. Suruhanjaya Polis Diraja Malaysia \& Anor; refd) (Mat Ghafar Baba v. Ketua Polis Negara \& Anor, refd).

Further, the learned judge while delivering the majority judgement held that the principles in the case Utra Badi and Vickneswary ${ }^{50}$ that states 'the right to be heard given by Article 135(2) of the Federal Constitution does not require that the person concerned be given an oral hearing' applies not in all cases and there are exceptions to this general rule.

The position became more exacerbated after YusufSudin's case when the same Federal Court in Kerajaan Malaysia \& Ors v. Tay Chai Huat ${ }^{51}$ upheld the principles in Utrabadi's case and Vickneswary's case and laid down a principle that if the Disciplinary Authority considered that no further clarification was required, then the officer facing the disciplinary charges could not insist that a committee of inquiry be appointed since the right to be heard under Article 135 (2) did not require an oral hearing. It is interesting to note that Mohd Ghazali Yusoff (FCJ) who delivered the majority judgment in this case, gave the dissenting judgement in Yusuf bin Sudin's case.

Further, the Court of Appeal in the case of Suruhanjaya PerkhidmatanAwamv.HjhMarinaHjMustafa ${ }^{52}$ referred to the caseofMat Ghaffar ${ }^{53}$.Itwasheld inMatGhafarthat:

It is settled principle that the right to be heard as enshrined in Art. 135 (2) of the Federal Constitution

50 [2008] 6 CLJ 573 FC. The Federal Court ruled that it is clear that it is never the intention of the legislator in General Orders to give an officer under disciplinary action right to give oral evidence. p. 257.

51 [2012] 3 MLJ 149 at $\mathrm{p} 150$. No request of oral hearing was made by the Respondent in this case.

52 [2015] 4 CLJ 312. The Court held that the right to a reasonable opportunity of being heard under art. 135(2) is not synonymous with a right to an oral hearing that should be granted according to the circumstances of the case at $\mathrm{p} 312$.

53 [2008] 1 CLJ 773. In this case, the Court of Appeal applied the principle in Ang Wan Seng. It was held that it was incumbent upon the Disciplinary Authority to initially consider the charges made against the public officer and to determine whether in the light of representation made by him an oral hearing was warranted. 
do not in all cases include the duty to afford an oral hearing. But as stated by Gopal Sri Ram, JCA in Raja Abdul Malek Muzaffar Shah ${ }^{54}$ :

"Cases may arise where, in the light of peculiar facts, the failure to afford an oral hearing may result in the decision arrived at being declared a nullity or quashed. (see $R$ v. Immigration Appeal Tribunal [1977] 1 WLR 795)."

In the recent case, Abdul Ghani Che Mat v. Pengerusi Suruhanjaya Pasukan Polis \& Ors, ${ }^{55}$ Court of Appeal held that the audi alteram partem rule states that a decision cannot stand unless the person directly affected by it is given a fair opportunity whether he has the right to state his case as well as to know and answer the other side's case. It was held inter alia that, the right of hearing is a right to the minimum standard of procedural fairness and must not be confused with the question of whether the officer was actually guilty of the disciplinary offences. In carrying out the disciplinary procedure, natural justice requires that the disciplinary authority must employ means that justifies the end rather than the end justifying the means.

In Abdul Ghani's case, the Court of Appeal referred to the Federal Court's decision in Rama Chandran v. The Industrial Court of Malaysia $^{56}$. Edgar Joseph Jr. FCJ in a landmark judgement of cardinal importance established that fairness included not only procedural fairness but substantive fairness as well. That decision was an important landmark in our administrative law jurisprudence.

In the most recent case, Vijayarao a/l Sepermaniam v. Suruhanjaya Perkhidmatan Awam Malaysia, ${ }^{57}$ the Court of Appeal held inter alia:

Where there is a request by the public officer for an oral hearing after he had denied all the charges and

\footnotetext{
54 [1995] 1 AMR 855. It was held by Court of Appeal inter alia (a) Even though the settled principle is that the right to be heard does not in all cases include a duty to afford an oral hearing, in certain cases the failure or refusal to afford such a hearing could render a decision null and void.

$55 \quad$ [2017] 3 CLJ 399 at p 400.

56 [1997] 1 MLJ 1

57 [2017] 4 CLJ 451 at p 452.
} 
appeared to have exculpated himself by furnishing credible evidence, the officer should be afforded an oral hearing. An oral hearing should be granted when there is a request and when the disciplinary authority is faced with two sets of facts, documents and evidence. The circumstances of each case must be fully considered before the court could come to the conclusion whether or not the right to an oral hearing has been properly observed by the disciplinary authority.

However, in its concluding remarks, the Court of Appeal reiterated that having carefully considered the circumstances surrounding this case, the Court was of the view that he had been given a fair opportunity to correct or contradict the evidence against him. In short, although no oral hearing was granted, the appellant had been given the full opportunity of stating his case in this case. The appellant then appealed to the Federal Court.

On further appeal, ${ }^{58}$ from the various authorities on the right to the oral hearing, the Federal Court was of the view that the law as currently adopted by the courts is more in favour of affording a right to be heard orally if there is a request made to the disciplinary authority. Therefore, it was held unanimously by the five judges that in the light of the facts and circumstances of the case, the appellant ought to have been given an oral hearing and related documents and reports as requested by him in his written representation to enable him to make an effective and meaningful defence to the charges against him.

\section{APPROACHES OF THE COURTS IN MALAYSIA}

Based on the above mentioned cases, though the issue of the right to be heard was deemed to be settled in Utra Badi's case and Vickneswari's case, that the right to be heard under Article 135 (2) of the Federal Constitution did not require a relevant public servant to be given an oral hearing and that it could not be argued that the failure to give that person an oral hearing was a denial of justice, ${ }^{59}$ in reality,

\footnotetext{
58 Vijayarao A/L Sepermaniam v Suruhanjaya Perkhidmatan Awam Malaysia [2018] MYFC 20

59 Kerajaan Malaysia \& Ors v Tay Chai Huat (2012) 3 MLJ 149 at p 150.
} 
the issue continues to be unresolved. To support this contention, we may refer to the Tay Chai Huat's case. The approach taken by the court was to bind itself with the ratio decidendi in Utra Badi's case and Vickneswary's case and to be a loyal adherence to the doctrine of stare decisis. ${ }^{60}$ In addition to that, the court took the approach to tie itself to the strict principle of the judicial review where once the Disciplinary Authority had complied with the procedural provisions related to the dismissal or reduction in rank, the court had no jurisdiction to consider the merit of the case. ${ }^{61}$

Whereas in the Yusuf bin Sudin's case the Court did not govern itself to the principle of Utrabadi's case and even ruled that the principle restricted only to its own facts where it did not cover the situation when the officer gave exculpatory statements and request for an oral hearing. The majority decision in Yusuf bin Sudin's case did not follow Utra Badi's and Vickneswary's cases. Richard Malanjum CJSS in his judgment made an observation regarding the connection of procedural fairness to fundamental rights as enshrined in the Federal Constitution. ${ }^{62}$

The latest authority in Vijayarao's case inclined to support the view of giving the right to oral hearing to the affected officer provided there is a request to the disciplinary authority. What may be expected is that, the judgement would be in the interest of a public servant if the court takes a liberal approach of incorporating that fundamental liberty of livelihood ${ }^{63}$ to Article 135(2).

The views of the courts about the right to oral hearing are varied depending on the facts and circumstances before the disciplinary authority. This is, at least in part, a result of the difficulty in defining the true intent behind the protective provisions of the Federal Constitution and the rules governing disciplinary action. Thus, it is contended here that the approach of the courts on the issue of the right to oral hearing are either liberal or restricted in the interpretation of the principle of judicial review and the doctrine of judicial precedents.

60 Tay Chai Huat's case at $\mathrm{p} 165$.

${ }_{61}$ Dissenting judgement in Yusuf bin Sudin's case at p 496.

62 Yusuf bin Sudin's case at p 459.

63 Article 5 of the Federal Constitution states that:

(1) No person shall be deprived of his life or personal liberty save in accordance with the law. 
The liberal approach can be seen in the case of Yusuf bin Sudin where the Federal Court made the observation of procedural fairness that is closely connected to a fundamental right, for instance, the right to life (art. 5[1]) as enshrined in our Federal Constitution is of paramount importance. And it has been said that 'income is the foundation of many fundamental rights and when work is the sole source of income, the right to work becomes as much a fundamental right. The court, in this case, is of the view that there should be an exception to the general rule (as set in Utra Badi's case) where oral hearing should be given.

Another liberal or progressive approach was shown by the Court of Appeal in Tan Tek Seng v Suruhanjaya Perkhidmatan Pendidikan \& Anor ${ }^{64}$ where the court had applied its creative ingenuity in interpreting Article 5 and 8 of the Federal Constitution in complement to Article 135(2). It gave a broad and liberal meaning to the word 'life' in Article 5 to include the right to livelihood. It also observed that the combined effect of Article 5 and 8 guaranteed a fair procedure and also a fair and just punishment and the concept of proportionality was applied in this case.

On the other hand, the courts in applying a restricted approach will follow the principle of judicial review assiduously. For instance in Tay Chai Huat, it was held by the Federal Court that the courts have very limited review powers over the administrative determinations of public bodies and are constrained to confirm the findings in disciplinary hearings. The court will only intervene in disciplinary cases where there was a fundamental procedural flaw. Meanwhile, the concept of proportionality applied by the Court of Appeal in Tan Tek Seng was overruled by the Federal Court in $\mathrm{Ng}$ Hock Cheng $v$ Pengarah Am Penjara Taiping \& Ors. ${ }^{65}$

Meanwhile, in Ghazi bin Mohd Sawi v Mohd Haniff bin Omar, Ketua Polis Negara ${ }^{66}$ when an issue arose at the appeal stage whether a government servant was entitled to an oral hearing or not, the court concluded that oral hearing was not obligatory under the relevant regulations. The court strictly observed (at p 130):

\footnotetext{
64 [1996] 1 MLJ 261 Court of Appeal

65 [1998] 1 CLJ 405

$66 \quad$ [1994] 2 MLJ 114
} 
In dealing with Chapter D of the 1980 General Orders, we remind ourselves that we are dealing with the General Orders that have a legislative effect and we must guard ourselves against adding words into them which were never intended....

This view of the Supreme Court gives the implication that the regulations constitute a final word on what is 'reasonable opportunity of being heard' guaranteed by Article 135(2).

In brief, the courts in its liberal approach will always expand the scope of the judicial review of administrative action. R Rama Chandran $v$ The Industrial Court of Malaysia and Anor ${ }^{67}$ is a landmark case in administrative law in Malaysia where according to Edgar Joseph Jr. FCJ the decision of the Federal Court in this case "pointed the way to new horizons in the forward march of judicial review."

On the contrary, the restricted approach connotes that the courts have very limited review powers over administrative determinations of public bodies and are constrained to confirm the findings in disciplinary hearings. The courts will only intervene in disciplinary cases where there is a fundamental procedural flaw. In other words, the courts strictly classified the grounds of judicial review to illegality, irrationality and procedural impropriety.

\section{CONCLUSION}

The government has incurred millions of ringgit in terms of compensation to public servants who are reinstated by the court due to procedural defects pertaining to the right of oral hearing in disciplinary proceedings since Independence. What complicates matters is that, Article 135(2) of the Federal Constitution is silent on the interpretation of the rule of being given "a reasonable opportunity of being heard," whether it shall be extended to the right of oral hearing that is regarded as part of procedural fairness. As a result of this ambiguity, there have been numerous cases related to the issue of the right to oral hearing under Article 135(2).

67 [1997] 1 MLJ 145 Federal Court 
This research has shown that reform of existing procedural laws on disciplinary proceedings is needed so that the rule of natural justice is truly served to public servants. Further, it has also submitted that the liberal approach be adopted by the court in determining the right to oral hearing in disciplinary proceedings against public servants. By providing the right to oral hearing, the decision of the Disciplinary Authority would no longer be subject to judicial review on the grounds of procedural inconformity.

\section{REFERENCES}

Abdul Ghani Che Mat v. Pengerusi Suruhanjaya Pasukan Polis \& Ors, [2017] 3 CLJ 399

Annual Report Public Service Department Malaysia. (2013). Percetakan Nasional Berhad.

Ann Seng Wan v. Suruhanjaya Polis Diraja Malaysia \& Anor. [2002] 1 CLJ 493

B. Surinder Singh Kanda v. Government of the Federation of Malaya [1962] MLJ 169 at p 172

Bird, R. (1983). Osborn's concise law dictionary (7th ed.). London: Sweet \& Maxwell, at p 227.

Cooper v Wandsworth Board of Works (1863) 14 CBNS 180; 143 ER 414

Fadzil bin Mohamed Noor v Universiti Teknologi, Malaysia [1981] 2 MLJ 196

Fariza Romli, Nuarrual Hilal Md Dahlan \& Rusniah Ahmad. (2012).

Prinsip keadilan asasi dalam undang-undang berkaitan prosedur perbicaraan tatatertib di Jabatan Polis: Suatu analisa. UUM Journal of Legal Studies, 3, 145-163.

Federal Constitution. (2017). Malaysia: The Commissioner of Law Revision.

Gan Ching Chuan. (2007). Disciplinary proceedings against public officers in Malaysia. Singapore: Lexis Nexis.

George Sampson Akpan. (2000). The public servant and security of employment: A comparative study. In Singapore Journal of International Comparative Law. Faculty of Law, National University of Singapore.

Ghazi bin Mohd Sawi v Mohd Haniff bin Omar, Ketua Polis Negara [1998] 1 CLJ 405

Jain. MP. (1983). Administrative law in the common-law countries: Recent developments and future trends. Journal of Malaysian Comparative Law, (June and December). 
Ketua Pengarah Kastam vs. Ho Kwan Seng [1977] 2 MLJ 152

Kerajaan Malaysia \& Ors v. Tay Chai Huat [2012] 3 MLJ 149

Lembaga Tatatertib Perkhidmatan Awam Hospital Besar Pulau

Pinang \& Anor v. Utra Badi Perumal

Mat Ghaffar Baba v. Ketua Polis Negara \& Anor, [2008] 1 CLJ 773

Mohd Ahmad v. Yang Di-Pertua Majlis Daerah Jempol, Negeri Sembilan and Anor (1997) 3 CLJ 135

MP Jain. (1997). Administrative law of Malaysia and Singapore.

(3rd ed.). Malayan Law Journal. Kuala Lumpur.

McInnes v Onslow-Fane [1978] 1 WLR 1520

Mullock v Abeedeen Corporation (1971) 2 All ER 1278, 1294

Najar Singh v Government of Malaysia \& Anor [1976] 1 MLJ 203

Nakkuda Ali v Jayaratne [1951] AC 66

Ng Hock Cheng v Pengarah Am Penjara Taiping \& Ors. [1998] 1 CLJ 405

Nik Ahmad Kamal Nik Mahmood. (2003). Perkhidmatan awam. In Ahmad Ibrahim, Faiza Thamby Chik, Ramlah Muhammad, Asiah Daud \& Ismail Hassan (Eds.), Perkembangan undangundang Perlembagaan Persekutuan (pp. 231-273). Kuala Lumpur: Dewan Bahasa dan Pustaka.

Peter S Crook. (1996). Natural justice and the constitution: Recent cases from the court of appeal. Journal of Malaysian and Comparative Law, 23 Part 1 \& 2, 37-56, p. 37.

Public Officer (Conduct and Discipline) 1993. (2017). International Law Book Services: Selangor Darul Ehsan.

Raja Abdul Malek Muzaffar Shah bin Raja Shahruzzaman v Setiausaha Suruhanjaya Pasukan Polis \& Ors. [1995] 1 MLJ 308

Ridge v Balwin [1964] AC 40

Rama Chandran v. The Industrial Court of Malaysia [1997] 1 MLJ 1

Ramalingam s/o Muthusamy v Chong Kim Fong [1978] 1 MLJ 83

Rosnelli Kundor $v$ Kelantan State Economic Development Corporation (2004) 4 CLJ 492

Rusniah Ahmad. (2013). Aplikasi prinsip dan kes-kes tatatertib. Sistem pengurusan tatatertib di tempat kerja. Sintok: Penerbit Universiti Utara Malaysia.

Tan Tek Seng v Suruhanjaya Perkhidmatan Pendidikan \& Anor, [1996] 1 MLJ 261

Shad Saleem Faruqi. (2008). Document of destiny: The Constitution of the Federation of Malaysia. Star Publication Berhad. 
Suhaila Shahrul Anuar (2017, April 19). Jumlah penjawat awam munasabah, Retrieved from https://www.bharian.com.my/ node $/ 273436$

Suruhanjaya Perkhidmatan Awam v. Hjh Marina Hj Mustafa [2015] 4 CLJ 312

The Queen v Metropolitan Police Commissioner, ex parte Parker [1953] 1 WLR 1150

V Ananta Raman, Natural Justice - The Malaysian Experience [1993] 3 MLJ i

Public Services Commission \& Anor $v$ Vickneswary a/p $R M$ Santhivelu [2008] 6 CLJ 573

Vijayarao a/l Sepermaniam $v$ Suruhanjaya Perkhidmatan Awam Malaysia [2018] MYFC 20

Yusof Sudin v. Suruhanjaya Perkhidmatan Polis \& Anor [2012] 1 CLJ 448 at $\mathrm{p} 450$

Zainal bin Hashim v Government of Malaysia [1979] 2 MLJ 276 